\title{
Arginine and Glutamate Levels in the Gingival Crevicular Fluid from Patients with Chronic Periodontitis
}

\author{
Narda TÉLLEZ \\ Natalia AGUILERA \\ Belkis QUIÑÓNEZ \\ Elizabeth SILVA \\ Luis Enrique GONZÁLEZ \\ Luis HERNÁNDEZ
}

Behavioral and Physiology Laboratory, School of Medicine, Universidad de Los Andes, Mérida, Venezuela

\begin{abstract}
The objectives of this study were to determine arginine and glutamate levels in the gingival crevicular fluid (GCF) of adult chronic periodontitis patients versus periodontally healthy controls, and to compare two kinds of microdialysis probes: normal and U-shaped probes. The analysis of GCF components was developed to improve the diagnosis of periodontal disease (PD). Proteolysis in the periodontal tissues increases the concentration of amino acids (aa) in the GCF and the levels of these aa may reveal PD features and stages. GCF samples were collected by microdialysis in situ from 5 periodontally affected sites (probing depth $\geq 5 \mathrm{~mm}$, clinical attachment loss $\geq 3 \mathrm{~mm}$ ) in 14 adult chronic periodontitis patients and from 14 adult periodontally healthy controls. Capillary zone electrophoresis coupled to laser induced fluorescence detection was used to measure concentration of arginine and glutamate in the GCF. Data were analyzed statistically by ANOVA and Tukey's post-hoc tests $(a ́=0.05)$. Arginine concentration was increased $(p<0.001)$ and glutamate concentration was decreased $(p<0.001)$ in chronic periodontitis patients as compared to controls. There were no significant differences $(\mathrm{p}=0.069)$ between the normal and U-shaped probes. In conclusion, the increase of arginine and decrease of glutamate concentration in GCF were associated to the presence of periodontitis, and might be used as markers to recognize periodontally susceptible subjects as well as to evaluate the treatment course.
\end{abstract}

Key Words: microdialysis, capillary electrophoresis, periodontitis, amino acids.

\section{INTRODUCTION}

Periodontal disease (PD) is a chronic inflammation caused mainly by microbial infection. PD reaction includes host's immune and inflammatory responses to microorganisms. Connective tissue destruction and loss of alveolar bone produce periodontal pockets with PD progression. The healthy gingival crevicular fluid (GCF) represents the transuded of gingival tissue interstitial fluid. However, in the course of gingivitis and periodontitis, GFC is transformed into true inflammatory exudate (1). Proteolysis in the periodontal tissues increases amino acids (aa) concentration in the GCF. During the inflammation, proteolytic enzymes are released in the periodontal tissue from leukocytes, acti- vated structural cells of epithelium and connective tissue (2), and from microbial enzymes. Porphyromona gingivalis, an anaerobic bacterial specie and important periodontal pathogen, is closely associated with inflammatory alveolar bone resorption (3). This microorganism produces arginine-gingipain, an enzyme specific for arginine. Gingipains strongly affect the host's defense system by degrading some cytokines and several immune cell receptors. Gingipains are able not only to cleave soluble TNF-alpha, but also to destroy the cytokine membrane, which may additionally deregulate the cytokine network (4). In addition to $P$. gingivalis, other associated bacteria like spyroqueta type and bacteroides gingivalis produce enzymes that have been used to evaluate PD (5). Arginine, an aa used as a substrate by several microorgan- 
isms, is the nitric oxide (NO) precursor. Arginine and glutamate could be potential markers to monitor PD progression and therapeutic effectiveness.

Different methods have been employed for collection of GCF samples including the use of absorbent paper strips inside the sulci or on its surface (6), fiber braids around and inside the sulci, collection with micropipettes by capillarity and washes into the sulci. The presence and functions of protein, especially enzymes in CGF, were first explored by Sueda et al. (7), Svansberg (8) and Akalin et al. (9). Analysis of the sample by colorimetric assay and chemical test identify some substances in the GCF, such as aspartate amino transferase (AST). At a mitochondrial level, AST synthesizes aspartate from oxalacetate, and alphacetoglutarate from glutamate and vice versa. AST has been reported to be a possible marker to distinguish between active and inactive pockets in $\mathrm{PD}(10,11)$. AST has been shown to be increased in PD in humans $(12,13)$. Some studies have detected sulfated glycosaminoglycans in GCF in significant amounts in sites with advanced and juvenile periodontitis with high metabolic bone activity (14). Aa analysis revealed that the composition of proteoglycan metabolites is be rich in glycine, serine and glutamic acid, which indicate that they might be biomarkers for active alveolar bone destruction (15).

In the present study, microdialysis was used to collect GCF samples from healthy subjects and periodontitis patients. Then arginine and glutamate levels were measured by means of capillary electrophoresis and laser induced fluorescence detection (CZE-LIFD). The samples were taken with a normal probe (16) and a U-shaped probe (17), which is designed to fit into the gingival margin, and GCF dialysates were analyzed using CZE-LIFD. The objectives of this study were to determine the extracellular concentration of arginine and glutamate in the CGF of adult chronic periodontitis patients versus periodontally healthy controls by a simple and non invasive method, and to compare two kinds of microdialysis probes: normal and U-shaped probes.

\section{MATERIAL AND METHODS}

The study purposes and design were fully explained to all volunteers who freely agreed to participate and signed an informed consent form approved by the Institutional Research Ethics Committee.

Twenty-eight subjects (16 female and 12 male; age range: 21-40 years) were assigned to two groups: periodontally healthy subjects ( $\mathrm{n}=14$; control) and patients with chronic periodontitis $(n=14)$. The patients were selected from those attending the Clinic of Periodontics of the Dental School of the Universidad de Los Andes (Merida, Venezuela). Chronic periodontitis was defined as the presence of at least 5 teeth with probing depth $\geq 5 \mathrm{~mm}$, clinical attachment loss $\geq 3 \mathrm{~mm}$ and radiographically confirmed bone loss. The 14 periodontal patients did not receive any treatment or antibiotic or non-steroidal antiinflammatory therapy in the 6 months prior to the study. The controls were selected from periodontally healthy volunteers, with no evidence of PD (normal radiographs, no clinical attachment loss or abnormal probing depth). Each group was divided into two subgroups: dialyzed with normal probes $(\mathrm{n}=7)$ and dialyzed with $U$-shaped probes $(n=7)$ in order to compare both types of microdialysis probes.

All 28 subjects received superficial prophylaxis at baseline to remove calculi and gross debris three days before sample collection. GCF samples were obtained from the anterolateral maxillary teeth: central incisor, lateral incisors and/or canines. The selected tooth region was isolated with cotton rolls and dried with cotton rolls, extending to the surrounding area. Each GCF sample was collected from the buccal region, mesial or distal thirds of the teeth using the microdialysis technique $(0.5 \mathrm{~mL}$ within in $30 \mathrm{~s})$. The probe was connected to a perfusion bomb with a syringe filled with saline (Ringer solution) maintaining a flow rate of $1 \mathrm{~mL} / \mathrm{min}$. The ultra-filtered solution obtained from the GCF was collected in a microtube made from a hematocrit tube. A total of $140 \mathrm{GCF}$ (chronic periodontitis and controls) were obtained and were stored frozen at $-70^{\circ} \mathrm{C}$ (Fig. 1).

\section{Microdialysis Procedure}

The normal (or classical) microdialysis probe was made from a concentric fused-silica polyamide covered capillary tubing ( $150 \mu \mathrm{m}$ OD x $75 \mu \mathrm{m}$ ID) in a 26 -gauge stainless steel tubing. A $200-\mu \mathrm{m}$ outer diameter, 13,000 molecular weight cutoff, cellulose hollow fiber was plugged with epoxy at one end and the other end was attached inside the 26-gauge tube with $3 \mathrm{~mm}$ of exposed cellulose (17). For the U-shaped probes, both ends of the cellulose hollow fiber were attached with epoxy inside two 26-gauge tubes leaving a 3-mmlong loop. The inlet tube of the microdialysis probe was 
connected to a syringe loaded with saline, which was delivered at a flow-rate of $1 \mu \mathrm{L} / \mathrm{min}$. Samples were collected every $30 \mathrm{~s}$ at volume of $0.5 \mu \mathrm{L}$.

\section{Derivatization Procedure}

Each sample was mixed with $0.2 \mu \mathrm{L}$ of a derivatizing solution made from $20 \mathrm{mM}$ carbonate buffer at $\mathrm{pH} 9.5$ and $0.5 \mu \mathrm{L}$ of $4 \times 10^{-4} \mathrm{M}$ fluorescein isothyocianate isomer I in acetone. The mixture was allowed to react in the dark for at least $18 \mathrm{~h}$ and then 3 $\mu \mathrm{L}$ of buffer were added to each vial. Standards were derivatized with the same protocol.

\section{Capillary Electrophoresis Procedure}

The concentration of arginine and glutamate in

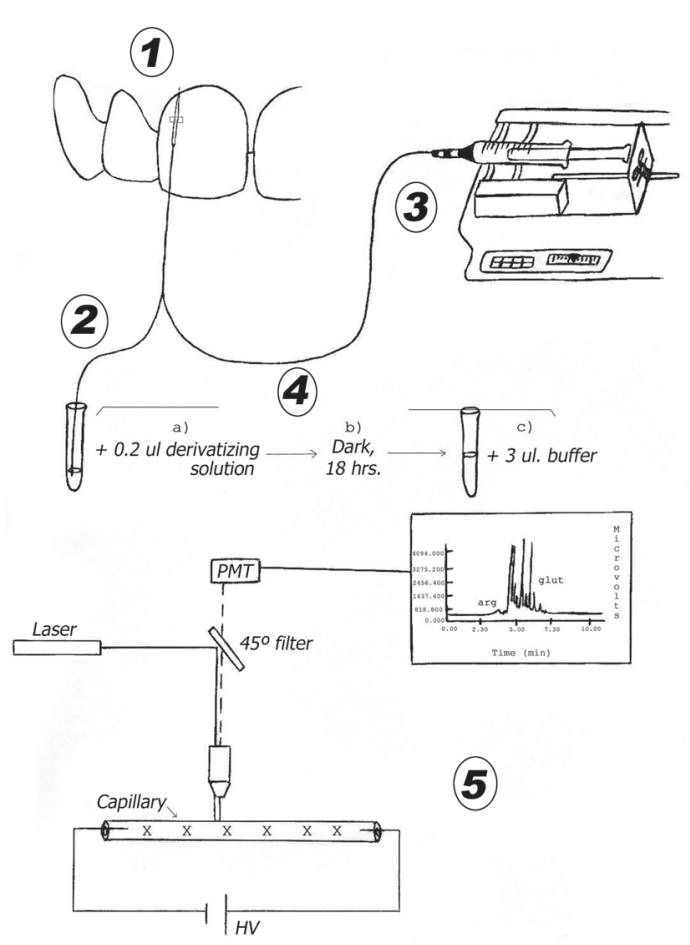

Figure 1. Schematic presentation of GCF sample collection and analysis. $1=$ Straight probe introduced in the gingival sulcus in the distobuccal region of a maxillary central incisor; $2=\mathrm{GCF}$ collected in a microhematocrit tube; $3=$ Other side of the probe connected to a syringe with Ringer solution in a perfusion pump; 4= Sample processing; 5= Reading in CZE-LIFD instrument. Derivatized sample injected in the CZE and information transformed in an electropherogram (Y microvolts; X time in min; arginine one of the initial peaks, glutamate one of the last peaks). HV: high voltage. the GCF was measured by capillary zone electrophoresis coupled to laser induced fluorescence detection (CZE-LIFD) in a model R2D2-1 instrument (Meridialysis $^{\mathbb{R}}$; Merida, Venezuela) equipped with a 60 cm-long, $350 \mu \mathrm{m}$ OD x $25 \mu \mathrm{m}$ ID fused silica capillary. The samples and the standards were hydrodynamically injected at the anodic end of the capillary by a negative pressure of 19 psi applied during $200 \mathrm{~ms}$ at the cathodic end of the capillary. Next, $21 \mathrm{kV}$ were applied between both ends of the capillary. The voltage generated a 7 microampere current. After each run, the capillary was flushed with $1 \mathrm{M} \mathrm{NaOH}(2 \mathrm{~min})$ followed by $18 \mathrm{M} \Omega$ water $(1 \mathrm{~min})$ and carbonate buffer $(4 \mathrm{~min})$. The peaks of the sample were identified by migration time and spiking. Peak height was measured and the concentration calculated by comparison with standard solutions.

\section{Statistical Analysis}

Data were analyzed statistically by ANOVA and Tukey's post-hoc tests at 5\% significance level.

\section{RESULTS}

The clinical characteristics of periodontal patients and controls are given in Table 1. There were no statistically significant $(\mathrm{p}=0.071)$ age or gender differences between the groups.

Arginine and glutamate concentration in controls were: arginine, normal probe: $2.40 \pm 0.02 \times 10^{-6} \mathrm{M}$; arginine, $U$-shaped probe: $2.96 \pm 0.08 \times 10^{-6} \mathrm{M}$; glutamate normal probe: $23.10 \pm 0.90 \times 10^{-6} \mathrm{M}$; glutamate, U-shaped probe: $30.40 \pm 1.00 \times 10^{-6} \mathrm{M}$.

Arginine and glutamate concentration in $\mathrm{PD}$ patient were: arginine, normal probe: $6.40 \pm 0.09 \times 10^{-}$ ${ }^{6} \mathrm{M}$; arginine, U-shaped probe: $10.00 \pm 0.09 \times 10^{-6} \mathrm{M}$; glutamate normal probe: $10.50 \pm 0.50 \times 10^{-6} \mathrm{M}$, glutamate, U-shaped probe: $8.72 \pm 0.20 \times 10^{-6} \mathrm{M}$.

Arginine concentration was significantly more elevated in patients with chronic periodontitis compared to controls $(\mathrm{p}<0.001)$ (Fig. 2), while glutamate was significantly decreased in chronic periodontitis patients $(p<0.001)$ (Fig. 3). There was significant difference in control normal probe vs. PD normal probe $(p<0.001)$ and control U-shaped probe vs. PD Ushaped probe $(p<0.001)$. However, there were no statistically significant differences $(p=0.069)$ between the normal and the U-shaped probes. 


\section{DISCUSSION}

The results of the present study suggest that the arginine increase and glutamate decrease in the GCF may be related to chronic periodontitis. The shape of the probes was found to be a non-relevant factor. These data are in accordance with those of previous studies showing that PD microorganisms degrade proteins to obtain arginine as their main energetic substrate. Therefore, it is possible that the level of arginine reflects the degree of bacterial activity in the chronic periodontitis $(4,18)$. Actinobacillus actinomycetemcomitans, Porphyromonas gingivalis and Prevotella intermedia produce arginine. Arginine increase might also be ex-

Table 1. Clinical characteristics of subjects in both groups.

\begin{tabular}{lcc}
\hline & $\begin{array}{c}\text { Periodontal } \\
\text { patients }\end{array}$ & $\begin{array}{c}\text { Healthy } \\
\text { controls }\end{array}$ \\
\hline Age (mean \pm SD) (yrs) & $32.7 \pm 5$ & $32.7 \pm 5$ \\
Age Range & $21-40$ & $21-40$ \\
Females & 8 & 8 \\
Males & 6 & 6 \\
PBD (mean \pm SD) (in $\mathrm{mm})$ & $4.2 \pm 0.9^{\mathrm{a}}$ & $0.9 \pm 0.3^{\mathrm{a}}$ \\
CAL (mean \pm SD) (in $\mathrm{mm})$ & $4.1 \pm 0.4^{\mathrm{b}}$ & $0.19 \pm 0.4^{\mathrm{b}}$ \\
$\%$ sites with plaque & $78 \%^{\mathrm{c}}$ & $22 \%^{\mathrm{c}}$ \\
$\%$ sites with BOP & $60.1 \%^{\mathrm{d}}$ & $1.6 \%^{\mathrm{d}}$ \\
\hline
\end{tabular}

aMean probing depth (PBD) in PD patients vs. controls ( $\mathrm{p}<0.0001)$; bMean clinical attachment loss (CAL) in PD patients vs. controls $(\mathrm{p}<0.0001) ;{ }^{c} \%$ of sites with plaque in PD patients vs. controls ( $<<0.0001$ ); ${ }^{\mathrm{d}} \%$ of sites with bleeding on probing (BOP) in PD patients vs. controls $(\mathrm{p}<0.0001)$.

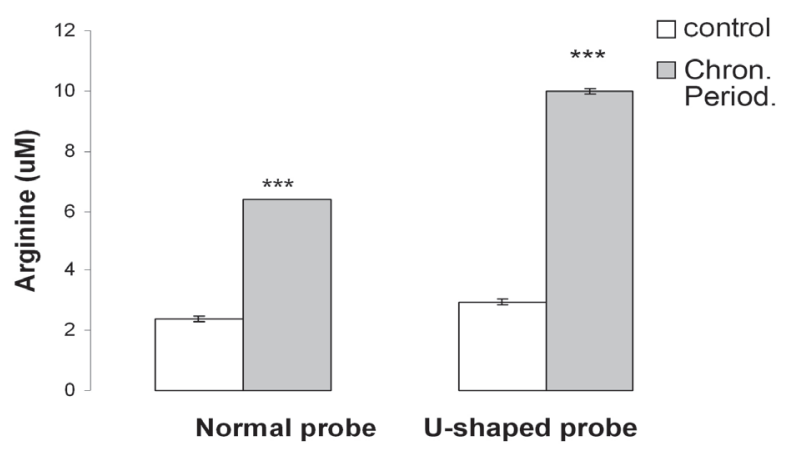

Figure 2. Periodontally healthy controls: white bars. Chronic periodontitis patients: gray bars. X: Arginine concentration ( $\mathrm{x} 10^{-}$ $\left.{ }^{6} \mathrm{M}\right)$. Y: Probe types. ${ }^{* * *}=\mathrm{p}<0.001$. plained because $P$. gingivalis, one of the major causative agents of $\mathrm{PD}$, produces large amounts of arginine and lysine by specific cystein proteinase, which are now referred to as Arg-ginpapain (Rgp) and Lysine-ginpapain (kgp) and are associated with $P$. gingivalis virulence (4). These enzymes are able to invade the epithelium cell barrier. Bone resorption is responsible for the morbidity associated with several inflammatory diseases, such as rheumatoid arthritis, orthopedic implant osteolysis, periodontitis and aural cholesteatoma. NO is generated from L-arginine by the enzyme nitric oxide synthase (NOS). Previous data have demonstrated a critical role for NOS I in inflammatory bone resorption and osteoclast function in vitro and in vivo (19). Syrjänsen et al. (20) analyzed several free aa in GCF and observed that only glutamate was significantly elevated in periodontal patients, while in the present study glutamate was significantly decrease in chronic periodontitis patients. These different results may be explained by a number of reasons: a) sample collection: Peritron papers into the gingival crevice vs. microdialysis probe into the sulci; $b$ ) number of patients: 5 vs. 14; c) technical analysis: automatic analyzer (4151 alpha Plus LKB, Biochrom, UK) vs. CZE-LIFD, a very sensitive method; d) arginine was not measurable in control subjects vs. measurement in both control and periodontal patients.

Aa analysis of sulphated glycosaminoglycans in GCF revealed the composition of the proteoglycan metabolites to be rich in glycine, serine and glutamic acid, so they might be biomarkers for active alveolar bone destruction. Decrease of glutamate might be present because pathogenic bacteria $(P$. gingivalis and $F$. Nucleatum and others) use glutamate in their meta-

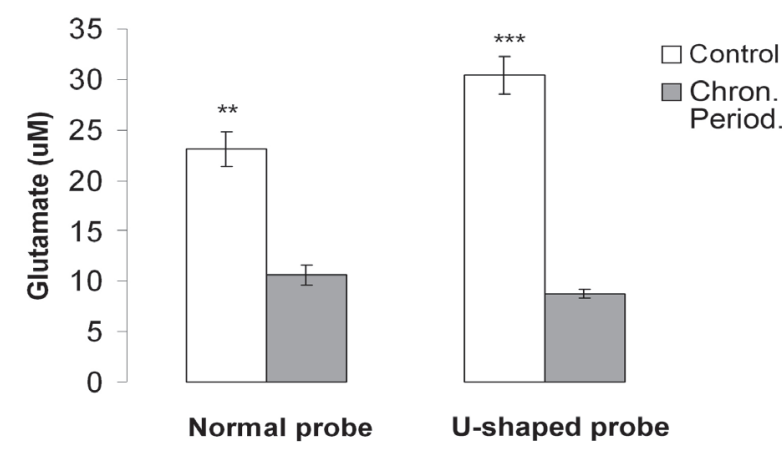

Figure 3. Periodontally healthy controls: white bars. Chronic periodontitis patients: gray bars. X: Glutamate concentration ( $\mathrm{x} 10^{-}$ $\left.{ }^{6} \mathrm{M}\right)$. Y: Probe types. ${ }^{* *}=\mathrm{p}<0.001 ; * * *=\mathrm{p}<0.0001$. 
bolic reactions. Dipeptides, such as aspartylaspartate and glutamylglutamate, can be used as growth substrates for $P$. gingivalis, $P$. intermedia, $P$. nigrescens and $F$. nucleatum to obtain energy and elaborate other compounds. Fusobacterium nucleatum has biosynthetic pathways only for three aa (glutamate, asparagines and aspartate) and the main source of energy seems to be the fermentation of glutamate to butyrate.

In conclusion, the increase of arginine and decrease of glutamate concentration in GCF were associated to the presence of periodontitis, and might be used as markers to recognize periodontally susceptible subjects as well as to evaluate the treatment course.

\section{RESUMO}

Os objetivos deste estudo foram determinar os níveis de arginina e glutamato no fluido gengival crevicular (FGC) em pacientes com periodontite crônica contra controles saudáveis e comparar dois tipos de cânulas de microdiálise: normais e em forma de U. A análise dos componentes do FGC desenvolveu-se para melhorar o diagnóstico da doença periodontal (DP). A proteólise dos tecidos periodontais aumenta a concentração de aminoácidos (aa) no FGC e os níveis destes aa podem revelar as características e estágios da DP. Amostras de FGC foram obtidas pela técnica de microdiálise in situ de cinco zonas com o periodonto afetado (profundidade de sondagem $\geq 5 \mathrm{~mm}$, perda da inserção clínica $\geq 3$ $\mathrm{mm}$ ) em 14 pacientes adultos com periodontite crônica e 14 controles saudáveis. Para medir a concentração de arginina e glutamato no GFC, usou-se a técnica de eletroforese capilar com detecção de fluorescência induzida por laser. Nos pacientes com periodontite crônica, a concentração de arginina aumentou significantemente $(p<0.001)$, enquanto a de glutamato diminuiu significantemente $(\mathrm{p}<0.001)$ em comparação aos controles. Não houve diferenças significantes $(\mathrm{p}=0.069)$ entre as cânulas normais e as cânulas em forma de U. Conclui-se que o aumento da concentração de arginina e diminuição de glutamato no FGC estavam associados à presença de periodontite, e podem ser usados como marcadores para identificar pacientes suscetíveis à periodontite bem como avaliar a evolução do tratamento.

\section{ACKNOWLEDGEMENTS}

This study was supported by grant CDCHT M-822-05-03 B and M-708-01-07-A.

\section{REFERENCES}

1. Lamster IB, Ahlo JK. Analysis of gingival crevicular fluid as applied to the diagnosis of oral and systemic diseases. Ann N Y Acad Sci 2007;1098:216-229.

2. Uitto V-J. Gingival crevicular fluid-an introduction. Periodontol 2000 2003;31:9-11.

3. Okahashi N, Inaba H, Nakagawa I, Yamamura T, Kuboniwa $\mathrm{M}$, Nakayama K, et al.. Porphyromonas gingivalis induces receptor activator of NF-kappaB ligand expression in osteoblasts through the activator protein 1 pathway. Infect Immun 2004;72:1706-1714

4. Uehara A, Naito M, Imamura T, Potempa J, Travis J, Nakayama K, et al: Dual regulation of interleukin-8 production in human oral epithelial cells upon stimulation with gingipains from Porphyromonas gingivalis. J Med Microbiol. 2008; 57(Pt 4): 500-507.

5. Oringer R, Howell H, Nevins M, Reasner D, Davis G, Sekler J et al.. Relationship between crevicular aspartate aminotransferase levels and periodontal Disease Progression. J Periodontol 2001;72:17-24.

6. Nakashima K, Demeurisse C, Cimasoni G. The recovery efficiency of various materials for sampling enzymes and polymorphonuclear leukocytes from gingival crevices. J Periodontology 1994;21:479-483.

7. Sueda T, Bang J, Cimasoni G. Collection of gingival fluid for quantitative analysis. J Dent Res 1969:48:159.

8. Svansberg GK. Hydroxyproline titers in gingival crevicular fluid. J Periodontal Res 1987;22:212-214.

9. Bildt MM, Bloemen M, Kuijpers-Jagtman AM, Von den Hoff JW. Collagenolytic fragments and active gelatinase complexes in periodontitis. J Periodontol. 2008; 79:1704-1711.

10. Eley BM, Cox SW. Advances in periodontal diagnosis. Potential markers of cell death and tissue degradation. Br Dent $\mathrm{J}$ 1998; 184:427-430

11. Shimada K, Mizuno T, Uchida T, Kato T, Ito K, Murai S. Relationship between levels of aspartate aminotransferase in gingival crevicular fluid and conventional measures of periodontal status assessed using PocketWatch ${ }^{\mathrm{TM}}$ : A cross-sectional study. J Oral Sci 1999;41:35-40.

12. Mizuho F, Mori H, Deguchi S, Ogawa Y, Hori T. Aspartate amino transferase (AST) levels in human periodontium-derived cells. J Periodontol 1996;67:733-736.

13. Chambers DA, Imrey B, Cohen RL, Crawford JM, Alves MEAF, McSwiggin TA. A longitudinal study of aspartate aminotransferase in human gingival crevicular fluid. J Periodont Res 1991;26:65-74.

14. Last KS, Stanbury JB, Emberg G. Glycosaminoglycans in human gingival crevicular fluid as indicators of active periodontal disease. Arch Oral Biol 1985;30:275-281.

15. Waddington RJ, Embery G, Smith AJ. Immunochemical detection of the proteoglycans decorin and biglycan in human gingival crevicular fluid from sites of advanced periodontitis. Arch Oral Biol 1998;43:287-295.

16. Hernandez L, Paez X, Hamlin C. Neurotransmitters extraction by local intracerebral dialysis in anesthetized rats. Pharmacol Biochem Behav 1983;18:159-162.

17. Hernandez L, Stanley B, Hoebel B. A small removable microdialysis probe. Life Sci 1986;39:2629-2677.

18. Hirose M, Ishihara K, Saito A, Nakagawa T, Yamada S, Okuda $\mathrm{K}$. Expresión of cytokines and inducible nitric oxide synthase in inflamed gingival tissue. J Periodontol 2001;72:590-597.

19. Leitão RB, Ribeiro RA, Chaves HV, Rocha FA, Lima V, Brito GA. Nitric oxide synthase inhibition prevents alveolar bone resorption in experimental periodontitis in rats. J Periodontol 2005;76:956-963.

20. Syrjänsen SM, Alakuijala L, Markkanen SO, Markkanen H. Free aminoacidlevels in oral fluids of normal subjects and patients with periodontal disease. Arch Oral Biol 1990;35:189-193. 